\title{
Characterization of Phosphorus in a Toposequence of Subtropical Perhumid Forest Soils Facing a Subalpine Lake
}

\author{
Yo-Jin Shiau ${ }^{1}(\mathbb{D})$, Chung-Wen Pai ${ }^{2}$, Jeng-Wei Tsai ${ }^{3}$, Wen-Cheng Liu ${ }^{4}$, Rita S. W. Yam ${ }^{5}{ }^{(\mathbb{C}}$, \\ Shih-Chieh Chang ${ }^{6}$, Sen-Lin Tang ${ }^{7}$ and Chih-Yu Chiu ${ }^{7, *}$ (1) \\ 1 Department of Safety, Health and Environmental Engineering, National Kaohsiung University of Science \\ and Technology, Kaohsiung 81164, Taiwan; yshiau@ncsu.edu \\ 2 The Experimental Forest, College of Bio-Resource and Agriculture, National Taiwan University, \\ Nantou 55743, Taiwan; cwpai724@yahoo.com.tw \\ 3 Department of Biological Science and Technology, China Medical University, Taichung 40402, Taiwan; \\ tsaijw@mail.cmu.edu.tw \\ 4 Department of Civil and Disaster Prevention Engineering, National United University, Miaoli 36063, Taiwan; \\ wcliu@nuu.edu.tw \\ 5 Department of Bioenvironmental Systems Engineering, National Taiwan University, Taipei 10617, Taiwan; \\ ritayam@ntu.edu.tw \\ 6 Department of Natural Resources and Environmental Studies, National Dong Hwa University, \\ Hualien 97401, Taiwan; scchang@mail.ndhu.edu.tw \\ 7 Biodiversity Research Center, Academia Sinica, Nangang, Taipei 11529, Taiwan; sltang@gate.sinica.edu.tw \\ * Correspondence: bochiu@sinica.edu.tw; Tel.: +886-2-2787-1180
}

Received: 1 May 2018; Accepted: 23 May 2018; Published: 25 May 2018

Abstract: The productivity of forests is often considered to be limited by the availability of phosphorus (P). Knowledge of the role of organic and inorganic $\mathrm{P}$ in humid subtropical forest soils is lacking. In this study, we used chemical fractionation and ${ }^{31} \mathrm{P}$ nuclear magnetic resonance (NMR) spectroscopy to characterize the form of $\mathrm{P}$ and its distribution in undisturbed perhumid Taiwan false cypress (Chamaecyparis formosensis Matsum.) forest soils. The toposequence of transects was investigated for the humic layer from summit to footslope and lakeshore. The clay layer combined with a placic-like horizon in the subsoil may affect the distribution of soil $\mathrm{P}$ because both total $\mathrm{P}$ and organic $\mathrm{P}\left(\mathrm{P}_{\mathrm{o}}\right)$ contents in all studied soils decreased with soil depth. In addition, $\mathrm{P}_{\mathrm{O}}$ content was negatively correlated with soil crystalline Fe oxide content, whereas inorganic $\mathrm{P}\left(\mathrm{P}_{\mathrm{i}}\right)$ content was positively correlated with soil crystalline Fe oxide content and slightly increased with soil depth. Thus, $P_{i}$ may be mostly adsorbed by soil crystalline Fe oxides in the soils. Among all extractable $\mathrm{P}$ fractions, the $\mathrm{NaOH}-\mathrm{P}_{\mathrm{o}}$ fraction appeared to be the major component, followed by $\mathrm{NaHCO}_{3}-\mathrm{P}_{\mathrm{o}}$; the resin-P and $\mathrm{HCl}-\mathrm{P}_{\mathrm{i}}$ fractions were lowest. In addition, we found no typical trend for $\mathrm{P}_{\mathrm{i}}$ and $\mathrm{P}_{\mathrm{o}}$ contents in soils with topographical change among the three sites. From the ${ }^{31} \mathrm{P}-\mathrm{NMR}$ spectra, the dominant $\mathrm{P}_{\mathrm{o}}$ form in soils from all study sites was monoesters with similar spectra. The ${ }^{31} \mathrm{P}-\mathrm{NMR}$ findings were basically consistent with those from chemical extraction. Soil formation processes may be the critical factor affecting the distribution of soil P. High precipitation and year-round high humidity may be important in the differentiation of the P species in this landscape.

Keywords: Chamaecyparis forest; humic substances; ${ }^{31} \mathrm{P}$ nuclear magnetic resonance spectroscopy ( ${ }^{31}$ P NMR); P species; topography 


\section{Introduction}

In terrestrial environments, mountainous forest is one of the canonical ecosystems that provide various ecosystem services such as maintaining biodiversity, water conservation [1] and carbon sequestration [2]. Meanwhile, it is also a vulnerable ecosystem that can be influenced by different soil nutrients [3]. Thus, understanding the soil nutrient distributions in a forest ecosystem is vital to maintain ecosystem functions and productivity [4]. In such ecosystems, phosphorus $(\mathrm{P})$ can be a limiting element because unlike nitrogen $(\mathrm{N})$, which is mainly deposited from the atmosphere [5], $\mathrm{P}$ is mostly acquired from weathering soil parent material and is continuously lost due to soil erosion [6-8]. The bioavailability of $\mathrm{P}$ in soils further relies on the chemical/physical conditions that fractionate the total $\mathrm{P}$ into different species $[9,10]$. Understanding $\mathrm{P}$ availability and its transformation among each fraction will help assess the P supply capacity of the soil over the long term and to adapt management practices [11].

Some isolated P fractionation pools have key functions in the P cycle and plant nutrition [11-15]. The organic and inorganic forms of $\mathrm{P}$ are usually separated and quantified by their plant availability. The mineralization of organic P is generally responsible for most of the P supply to plants [16,17], especially in mountain forest ecosystems [4,11,18]. Actually, the sequential fraction can provide a general indicator of how biological and geochemical forms of $\mathrm{P}$ change during soil weathering in mountain forest ecosystems. In general, organic P was found to be the dominant fraction of total P (TP) in these forest ecosystems, and available P content was determined by the mineralization processes of organic P [11,19]. Productivity, including plant growth and biomass production of trees in afforested mountain areas, is largely influenced by mineralization and microbial processes of organic $\mathrm{P}$ as well as soil organic matter.

However, identifying different fractions of $\mathrm{P}$ and evaluating their bioavailability are difficult because of spatial inconsistency and the complexity of geochemical properties. Several wet-chemical methods for determining P fractionations have been established and used in various ecosystems [20-23]. Also, ${ }^{31} \mathrm{P}$-nuclear magnetic resonance (NMR) spectroscopy has been used for determining the composition of soil P [24-26]. De Feudis et al. [27] determined the P availability in subalpine forest soils in Italy and found organic $\mathrm{P}$, bioavailable $\mathrm{P}$ contents and alkaline mono-phosphatase activity were all increased with altitude. Similarly, Doolette et al. [28] analyzed P composition in five alpine and subalpine forest soils and found that $54 \%$ to $66 \%$ of extractable P was contributed by organic P such as phosphomonoesters and inositol phosphonates, and the organic P composition was affected by temperature and soil moisture.

To our knowledge, studies of $\mathrm{P}$ fractionation in forests were mostly performed in temperate ecosystems $[10,29,30]$, with relatively fewer studies from subtropical and tropical alpine forests. In this study, to evaluate the pedogenetic effects on the forms of $\mathrm{P}$, we determined the composition of soil $\mathrm{P}$ with both chemical extraction and ${ }^{31} \mathrm{P}-\mathrm{NMR}$ methods along a toposequence in a pristine subtropical subalpine forest. Because the changes in soil oxidation-reduction status affect the formation of iron (Fe) and consequently the $\mathrm{P}$ status in such humid forest soils, we hypothesized that the content of labile $\mathrm{P}$ associated with Fe oxides increases with changing topographic sequence from the summit to lakeshore because of leaching and soil erosion, whereas recalcitrant organic $\mathrm{P}$, which is more complex-formed, will remain in the summit.

\section{Materials and Methods}

\subsection{Study Sites}

This study was conducted in the Yuanyang Lake forest ecosystem $\left(24^{\circ} 35^{\prime} \mathrm{N}, 121^{\circ} 24^{\prime} \mathrm{E}\right)$ in northeastern Taiwan. The study sites covered an elevation of 1700 to $2000 \mathrm{~m}$ a.s.1., with an average annual temperature of $12.5^{\circ} \mathrm{C}$ and a mean annual precipitation of more than $4000 \mathrm{~mm}$. The ecosystem consists of a primary forest dominated by Taiwan false cypress (Chamaecyparis obtusa var. formosana) and an evergreen broadleaf shrub (Rhododendron formosanum Hemsl.). The bedrock of the study sites 
is composed of interbedded Tertiary shale and sandstone [31]. This locality can be described as a temperate, very wet and mountainous ecosystem. It has been established as a Nature Reserve and selected as one of the long-term ecological research sites in Taiwan. The forest soils are divided into three main groups, which are closely related to the topography. The soil at the summit, with a slope of about $15^{\circ}$, is classified as Typic Hapludult (Ultisols) [32], which is relatively well-drained and develops clear eluvial and illuvial boundaries. The footslope, with a slope of about $28^{\circ}$, is dominated by Typic Dystrochrept (Inceptisols), where poor drainage caused by the clay and silty clay mineral horizon beneath the organic layer limits the downward movement of soluble compounds and thus hampers the soil profile development. Lithic Medihemist (Histosols) stretches from the lakeshore to the toeslope, about $1.5 \mathrm{~m}$ above the lake and with a slope of about $10^{\circ}$, which is inundated by occasional storms. Details of the environment of this ecosystem are described elsewhere [33]. Briefly, the soils at the summit and footslope are derived from partially podzolized soils and pure peats, while the soils at the lakeshore are mostly derived from peat, and directly lie on the bedrock [33].

\subsection{Soil Sampling}

A pedon sample was collected from each site to the bedrock. However, the pedon sample at the lakeshore was limited to the $\mathrm{O}$ horizon because no mineral layers were developed on the bedrock. Each horizon in the pedon was collected separately to determine the basic soil physiochemical properties.

To further determine the P fractionation along the topography, soil samples were collected from three selected sites along a topographic sequence in the forest that covered the summit, footslope and lakeshore. At each sampling site, three composite samples, each containing five subsamples, were collected with a soil auger with $8 \mathrm{~cm}$ in diameter and $10 \mathrm{~cm}$ in depth $\left(\mathrm{O}_{\mathrm{e}}\right.$ and $\mathrm{O}_{\mathrm{a}}$ horizons).

Visible coarse organic materials, such as roots and litter were manually removed before sieving. The remaining soil samples were air dried and sieved through a 2-mm sieve for chemical analysis.

\subsection{General Soil Chemical Properties}

Soil $\mathrm{pH}$ was measured at a soil:water ratio of 1:1. Total organic C (TOC) and total N (TN) contents in the soil were determined with an NCS Elemental Analyzer (Model NA1500 Fisons, Milan, Italy). Cation-exchange capacity was determined by the $\mathrm{NH}_{4} / \mathrm{Na}$ exchange method [34]. Crystalline $\mathrm{Fe}\left(\mathrm{Fe}_{\mathrm{d}}\right)$ and $\mathrm{Al}\left(\mathrm{Al}_{\mathrm{d}}\right)$ oxide contents were calculated by difference between dithionite and oxalate contents with following the experiments of previous study [35]. Amorphous $\mathrm{Fe}\left(\mathrm{Fe}_{\mathrm{o}}\right)$ and $\mathrm{Al}\left(\mathrm{Al}_{\mathrm{o}}\right)$ oxide contents were measured by an ammonium oxalate extraction method [36].

\subsection{Sequential Fractionation of $P$}

Sequential fractionation was performed as described in [37]. The sequential fractionation procedure removes progressively less available $\mathrm{P}$ with each subsequent soil extraction [38]. The fractionation started with $0.5 \mathrm{~g}$ dried sieve soil. An anion exchange resin was used first to extract plant-available inorganic $P$ (resin- $P_{i}$ ) [39]. Then, the other $P_{i}$ content was determined directly in $0.5 \mathrm{M} \mathrm{NaHCO}_{3}, 0.1 \mathrm{M} \mathrm{NaOH}, 1 \mathrm{M} \mathrm{HCl}$ and concentrated $\mathrm{HCl}$ extractions. The extracted solutions were then digested with $\mathrm{H}_{2} \mathrm{SO}_{4}(97 \%)$ and $\mathrm{H}_{2} \mathrm{O}_{2}(30 \%)$ at $300{ }^{\circ} \mathrm{C}$ to determine the total dissolved $\mathrm{P}$ $\left(\mathrm{P}_{\mathrm{d}}\right)$ content of each fraction. The organic $\mathrm{P}\left(\mathrm{P}_{\mathrm{o}}\right)$ content was calculated by subtracting $\mathrm{P}_{\mathrm{i}}$ content from $\mathrm{P}_{\mathrm{d}}$ content in each fraction $\left(\mathrm{P}_{\mathrm{o}}=\mathrm{P}_{\mathrm{d}}-\mathrm{P}_{\mathrm{i}}\right)$. The remaining soil was digested with $\mathrm{H}_{2} \mathrm{SO}_{4}(97 \%)$ and $\mathrm{H}_{2} \mathrm{O}_{2}(30 \%)$ at $300{ }^{\circ} \mathrm{C}$ to determine the residual $\mathrm{P}$ content. All extracts and digestions obtained were measured colourimetrically by the malachite green procedure [40].

Summed $\mathrm{P}_{\mathrm{i}}$ content was calculated as the sum of all analyzed $\mathrm{P}_{\mathrm{i}}$ fractions including resin- $\mathrm{P}_{\mathrm{i}}$, $\mathrm{NaHCO}_{3}-\mathrm{P}_{i}, \mathrm{NaOH}-\mathrm{P}_{i}, \mathrm{HCl}-\mathrm{P}_{\mathrm{i}}$ and $\mathrm{cHCl}-\mathrm{P}_{\mathrm{i}}$. Summed $\mathrm{P}_{\mathrm{o}}$ content was calculated as the sum of all analyzed $\mathrm{P}_{\mathrm{o}}$ fractions including $\mathrm{NaHCO}_{3}-\mathrm{P}_{\mathrm{o}}, \mathrm{NaOH}-\mathrm{P}_{\mathrm{o}}$ and $\mathrm{cHCl}-\mathrm{P}_{\mathrm{o}}$. Summed $\mathrm{P}$ content was calculated as the sum of $\mathrm{P}_{\mathrm{i}}, \mathrm{P}_{\mathrm{o}}$ and residual $\mathrm{P}$ content. Total $\mathrm{P}$ content of the soil samples was determined by digestion with $\mathrm{H}_{2} \mathrm{SO}_{4}(97 \%)$ and $\mathrm{H}_{2} \mathrm{O}_{2}(30 \%)$ at $300{ }^{\circ} \mathrm{C}$. 


\section{5. ${ }^{31}$ P-NMR Measurements}

Air-dried soil ( $5 \mathrm{~g})$ was dispersed in $20 \mathrm{~mL}$ of $0.25 \mathrm{M} \mathrm{NaOH}-0.05 \mathrm{M}$ EDTA for $2 \mathrm{~h}$, and the suspension was centrifuged at $12,100 \times g$ for $30 \mathrm{~min}$. The extractant was then reacted with chelating resin for $6 \mathrm{~h}$ at room temperature to reduce the paramagnetic interference of iron and other metals in the NMR spectra. After being stirred, the resin was separated by filtration through Whatman 42 filter paper. The extract was freeze-dried for storage. A freeze-dried sample $(0.1 \mathrm{~g})$ of NaOH-EDTA extractant was dissolved in $0.5 \mathrm{~mL}$ of $0.5 \mathrm{M} \mathrm{NaOH}$; then, $0.1 \mathrm{~mL} \mathrm{D}_{2} \mathrm{O}$ was added, and the solution was transferred to a 5-mm NMR tube for ${ }^{31} \mathrm{P}-\mathrm{NMR}$ analysis [41]. The ${ }^{31} \mathrm{P}-\mathrm{NMR}$ spectra were obtained at $242.86 \mathrm{MHz}$ and $25^{\circ} \mathrm{C}$ on a Bruker-600 NMR spectrometer with $60^{\circ}$ pulse, 3.5-s delay and 0.33-s acquisition time. The ${ }^{31} \mathrm{P}-\mathrm{NMR}$ spectra were proton-decoupled by using an inverse-gated pulse sequence to overcome the nuclear Overhauser enhancement and for quantification [40,41]. Depending on the P content in the alkaline extract, 500-2500 scans were used for an acceptable signal-to-noise ratio. Spectra were recorded with a line-broadening of $20 \mathrm{~Hz}$. The chemical shift was measured relative to an external $85 \% \mathrm{H}_{3} \mathrm{PO}_{4} / \mathrm{D}_{2} \mathrm{O}$ standard. The assignment of signals was based on Newman and Tate [42], Dai et al. [43], Condron et al. [24], and Robinson et al. [41]. Contents of the various P components (phosphonate, inorganic orthophosphate, orthophosphate monoesters, orthophosphate diesters, pyrophosphate, polyphosphates) were determined according to relative resonance areas obtained by electronic integration. Inorganic orthophosphates and orthophosphate monoesters signals were separated by using a boundary determined from the valley between the two signals to the baseline [44].

\subsection{Statistical Analyses}

All extraction experiments were carried out in triplicate. Simple linear regression was used to compare the relation between soil $\mathrm{P}$ and soil $\mathrm{Fe}_{\mathrm{d}}, \mathrm{Fe}_{\mathrm{o}} \mathrm{Al}_{\mathrm{d}}$ and $\mathrm{Al}_{\mathrm{o}}$ concentrations. Differences in the $\mathrm{P}$ factions among the three sites were analyzed using one-way analysis of variance (One-Way ANOVA) and Tukey's honestly significant difference (HSD) test. JMP 11.0 (SAS Inc., Cary, NC, USA) was used for these statistical analyses. $p<0.05$ was considered as statistically significant.

\section{Results}

The basic chemical properties of the studied soils are in Table 1. The soils were strongly acidic; $\mathrm{pH}$ values ranged from 3.3 to 4.5 in the three sampling sites. Both TOC and TN contents were high in the O horizon and decreased from the surface to the low horizons. Similarly, the cation-exchange capacity basically decreased from the surface to the low horizons. Total P content also decreased from the surface to the low horizons, but the difference was much less than for TOC and TN contents.

The $\mathrm{Fe}_{\mathrm{o}}, \mathrm{Fe}_{\mathrm{d}}, \mathrm{Al}_{\mathrm{o}}$ and $\mathrm{Al}_{\mathrm{d}}$ contents peaked in the $\mathrm{Bt}_{2}$ horizon at the summit site and in the $\mathrm{Bw}_{2}$ horizon at the footslope site. $\mathrm{P}_{\mathrm{i}}$ content was associated with amorphous $\left(\mathrm{Fe}_{\mathrm{o}}\right.$ and $\left.\mathrm{Al}_{\mathrm{o}}\right)$ and crystalline $\left(\mathrm{Fe}_{\mathrm{d}}\right.$ and $\left.\mathrm{Al}_{\mathrm{d}}\right) \mathrm{Al}$ and $\mathrm{Fe}$ oxide contents and migrated vertically through the horizons with illuviation. Moreover, $\mathrm{P}_{\mathrm{i}}$ and $\mathrm{Fe}_{\mathrm{d}}$ contents were positively correlated, and $\mathrm{P}_{\mathrm{o}}$ and $\mathrm{Fe}_{\mathrm{d}}$ as well as $\mathrm{P}_{\mathrm{o}}$ and $\mathrm{Fe}_{\mathrm{o}}$ contents were negatively correlated in the soil samples (Figure 1a). However, the relation between $\mathrm{P}_{\mathrm{i}}$ and $\mathrm{Fe}_{\mathrm{o}}$ contents was not statistically significant (Figure $1 \mathrm{~b}$ ). In addition, only $\mathrm{P}_{\mathrm{i}}$ and $\mathrm{Al}_{\mathrm{o}}$ contents were positively correlated; $\mathrm{P}_{\mathrm{o}}$ and $\mathrm{Al}_{d}$ contents were negatively correlated but not $\mathrm{P}_{\mathrm{i}}$ and $\mathrm{Al}_{d}$ nor $\mathrm{P}_{\mathrm{o}}$ and $\mathrm{Al}_{\mathrm{o}}$ contents (Figure $2 \mathrm{a}, \mathrm{b}$ ).

Contents of total $\mathrm{P}$ and summed $\mathrm{P}$ and $\mathrm{P}_{\mathrm{i}}$ in the $\mathrm{O}$ horizons were greater at the footslope than the lakeshore, whereas the values in the summit site were in between those at the footslope and lakeshore. In addition, summed $\mathrm{P}_{\mathrm{o}}$ and residual $\mathrm{P}$ contents were similar among the three sites (Table 2). HCl- $\mathrm{P}_{\mathrm{i}}$ and $\mathrm{cHCl}-\mathrm{P}_{\mathrm{i}}$ contents were similar among the three sites, whereas $\mathrm{cHCl}-\mathrm{P}_{\mathrm{o}}$ content in the footslope soil was similar to that at the lakeshore but higher than that at the summit. $\mathrm{NaOH}-\mathrm{P}_{\mathrm{i}}$ content was higher at the footslope than the summit and lakeshore. In addition, $\mathrm{NaOH}-\mathrm{P}_{\mathrm{o}}$ content was higher at the summit than the footslope and lakeshore. $\mathrm{NaHCO}_{3}$ extracted $\mathrm{P}_{\mathrm{i}}$ content was higher at the summit than 
the footslope and lakeshore, whereas $\mathrm{NaHCO}_{3}-\mathrm{P}_{\mathrm{o}}$ content was the highest at the footslope and was similar at the summit and lakeshore. Resin- $P_{i}$ content was higher at the lakeshore than the footslope, and resin- $P_{i}$ content at the summit was in between that at the other two sites.
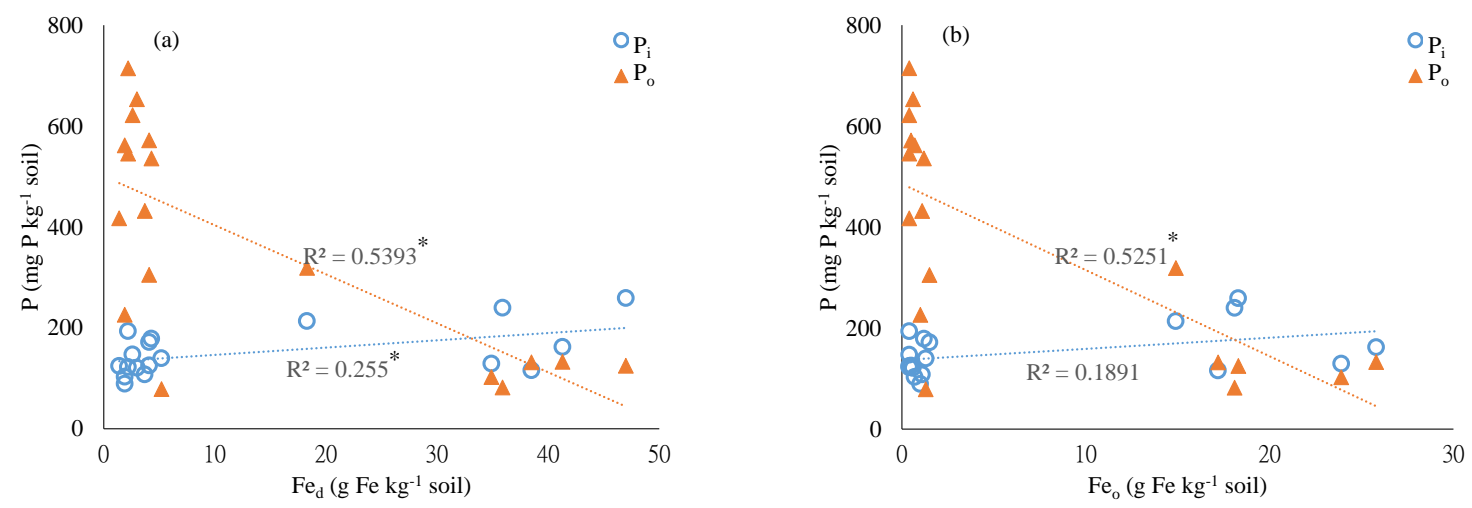

Figure 1. Correlations of contents of $\mathrm{P}_{\mathrm{i}}$ and $\mathrm{P}_{\mathrm{o}}$ with $\mathrm{Fe}_{\mathrm{d}}(\mathbf{a})$ and $\mathrm{Fe}_{\mathrm{o}}(\mathbf{b})$ in the pedon samples collected from the three sampling sites. ${ }^{*}$ Statistically significant at $p<0.05$.
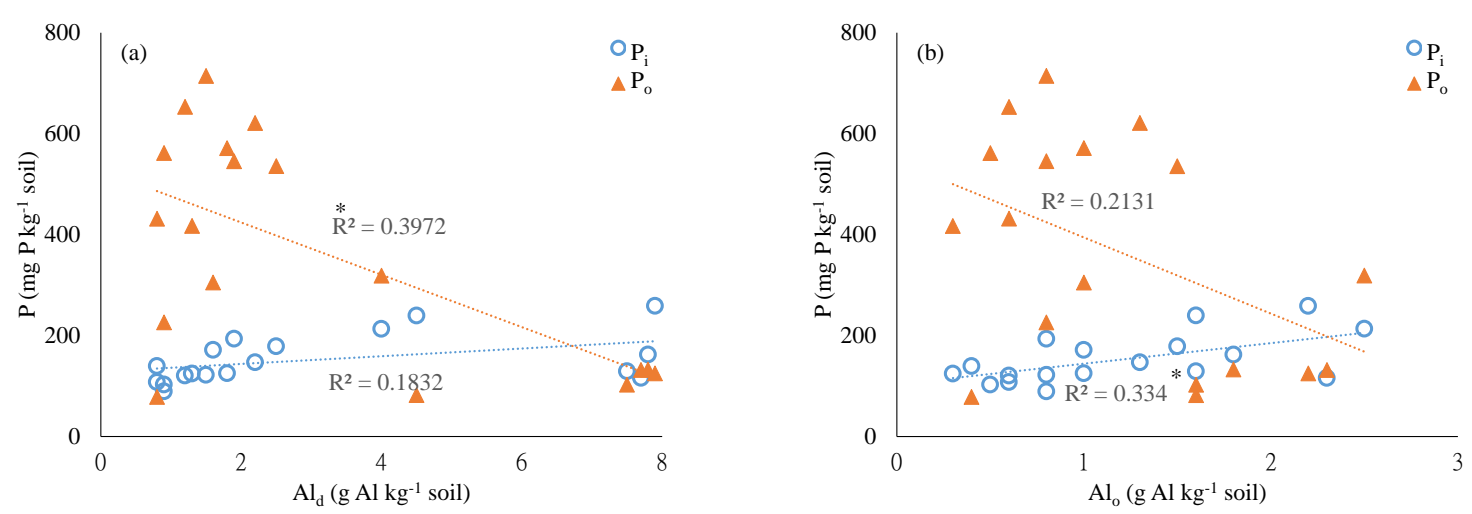

Figure 2. Correlations of contents of $\mathrm{P}_{\mathrm{i}}$ and $\mathrm{P}_{\mathrm{o}}$ with $\mathrm{Al}_{\mathrm{d}}(\mathbf{a})$ and $\mathrm{Al}_{\mathrm{O}}(\mathbf{b})$ in the pedon samples collected from the three sampling sites. * Statistically significant at $p<0.05$.

Organic $\mathrm{P}$ was the dominant $\mathrm{P}$ fraction in the mountain forest soils of the three sites (Table 3). Moreover, $\mathrm{NaOH}-\mathrm{P}_{\mathrm{o}}$ represented the major $\mathrm{P}$ fraction and contributed to more than $40 \%$ of the summed $\mathrm{P}$ content at the three sampling sites. $\mathrm{NaHCO}_{3}-\mathrm{P}_{\mathrm{o}}$ was the second most abundant $\mathrm{P}$ fraction among the three sites and contributed more than $20 \%$ of the summed $\mathrm{P}$ content. Summed $\mathrm{P}_{\mathrm{i}}$ content (resin- $\mathrm{P}_{\mathrm{i}}$ $\left.+\mathrm{NaHCO}_{3}-\mathrm{P}_{\mathrm{i}}+\mathrm{NaOH}-\mathrm{P}_{\mathrm{i}}+\mathrm{HCl}-\mathrm{P}_{\mathrm{i}}+\mathrm{cHCl}-\mathrm{P}_{\mathrm{i}}\right)$ in surface soils of all study sites contained less than $18 \%$ of summed $\mathrm{P}$, and $\mathrm{NaOH}-\mathrm{P}_{\mathrm{i}}$ was the major $\mathrm{P}_{\mathrm{i}}$ fraction in total $\mathrm{P}_{\mathrm{i}}$. 
Table 1. General chemical properties of studied soils.

\begin{tabular}{|c|c|c|c|c|c|c|c|c|c|c|c|c|c|c|}
\hline Site & Horizon & $\begin{array}{l}\text { Depth } \\
\text { (cm) }\end{array}$ & $\mathrm{pH}$ & $\begin{array}{c}\text { CEC } \\
\left(\mathrm{cmol}_{(+)} \mathbf{k g}^{-1}\right) \\
\end{array}$ & $\begin{array}{c}\text { Base Saturation } \\
(\%)\end{array}$ & $\begin{array}{c}\text { TOC } \\
\left(\mathrm{g} \mathrm{kg}^{-1}\right)\end{array}$ & $\begin{array}{l}\text { Total N } \\
\left(\mathrm{g} \mathrm{kg}^{-1}\right)\end{array}$ & $\begin{array}{c}\text { Total P } \\
\left(\mathrm{mg} \mathrm{kg}^{-1}\right)\end{array}$ & $\begin{array}{c}\mathbf{P}_{\mathbf{i}} \\
\left(\mathrm{mg} \mathrm{kg}^{-1}\right)\end{array}$ & $\begin{array}{c}\mathrm{P}_{\mathrm{o}} \\
\left(\mathrm{mg} \mathrm{kg}^{-1}\right)\end{array}$ & $\begin{array}{c}\mathrm{Fe}_{\mathbf{o}} \\
\left(\mathrm{g} \mathrm{kg}^{-1}\right)\end{array}$ & $\begin{array}{c}\mathrm{Fe}_{\mathrm{d}} \\
\left(\mathrm{g} \mathrm{kg}^{-1}\right)\end{array}$ & $\begin{array}{c}\mathrm{Al}_{\mathrm{o}} \\
\left(\mathrm{g} \mathrm{kg}^{-1}\right)\end{array}$ & $\begin{array}{c}\mathrm{Al}_{\mathrm{d}} \\
\left(\mathrm{g} \mathrm{kg}^{-1}\right)\end{array}$ \\
\hline \multirow[t]{8}{*}{ Summit } & $\mathrm{O}_{\mathrm{i}}$ & $+10 \sim+7$ & 3.7 & 73.1 & 1.2 & 352.4 & 8.88 & 945.8 & 125.5 & 571.6 & 0.5 & 4.1 & 1.0 & 1.8 \\
\hline & $\mathrm{O}_{\mathrm{e}}$ & $+7 \sim+2$ & 3.5 & 124.9 & 3.3 & 492.5 & 17.49 & 1040.2 & 147.2 & 621.4 & 0.4 & 2.6 & 1.3 & 2.2 \\
\hline & $\mathrm{O}_{\mathrm{a}}$ & $+2 \sim 0$ & 3.5 & 146.9 & 2.3 & 492.4 & 22.1 & 606.7 & 178.6 & 535.8 & 1.2 & 4.3 & 1.5 & 2.5 \\
\hline & A & $0 \sim 1$ & 3.5 & 60.1 & 1.8 & 207.3 & 11.9 & 667.8 & 171.7 & 305.2 & 1.5 & 4.1 & 1.0 & 1.6 \\
\hline & $\mathrm{E}$ & $1 \sim 8$ & 3.8 & 19.5 & 4.6 & 38.0 & 1.9 & 308.1 & 89.3 & 226.1 & 1.0 & 1.9 & 0.8 & 1.0 \\
\hline & $\mathrm{Bt}_{1}$ & $8 \sim 20$ & 4.1 & 19.6 & 4.1 & 10.0 & 0.95 & 194.2 & 116.0 & 131.9 & 17.2 & 38.5 & 2.3 & 7.7 \\
\hline & $\mathrm{Bt}_{2}$ & 20 30 & 4.2 & 12.4 & 6.5 & 11.9 & 1.07 & 269.0 & 162.2 & 132.8 & 25.8 & 41.3 & 1.8 & 7.8 \\
\hline & BC & $30 \sim 45$ & 4.3 & 12.7 & 3.9 & 9.0 & 1.06 & 245.8 & 129.3 & 102.6 & 23.9 & 34.9 & 1.6 & 7.5 \\
\hline \multirow[t]{7}{*}{ Footslope } & $\mathrm{O}_{\mathrm{i}}$ & $+11 \sim+8$ & 3.8 & 98.9 & 10.6 & 541.7 & 12.8 & 905.0 & 122.3 & 714.5 & 0.4 & 2.2 & 0.8 & 1.5 \\
\hline & $\mathrm{O}_{\mathrm{e}}$ & $+8 \sim+4$ & 3.5 & 120.3 & 5.3 & 511.8 & 19.1 & 701.6 & 120.8 & 653.2 & 0.6 & 3.0 & 0.6 & 1.2 \\
\hline & $\mathrm{O}_{\mathrm{a}}$ & $+4 \sim 0$ & 3.3 & 102.9 & 5.0 & 476.7 & 22.9 & 402.5 & 193.6 & 545.5 & 0.4 & 2.2 & 0.8 & 1.9 \\
\hline & $\mathrm{A}$ & $0 \sim 5$ & 3.5 & 65.3 & 2.6 & 237.6 & 12.9 & 305.9 & 213.4 & 318.9 & 14.9 & 18.3 & 2.5 & 4.0 \\
\hline & E & $5 \sim 10$ & 4 & 11.5 & 7.8 & 7.0 & 0.7 & 171.7 & 139.7 & 78.7 & 1.3 & 5.2 & 0.4 & 0.8 \\
\hline & $\mathrm{Bw}_{1}$ & $10 \sim 23$ & 4.1 & 16.6 & 2.4 & 10.0 & 1.1 & 283.8 & 239.7 & 82.0 & 18.1 & 35.9 & 1.6 & 4.5 \\
\hline & $\mathrm{Bw}_{2}$ & $23 \sim 42$ & 4.5 & 17.6 & 4.5 & 19.9 & 1.5 & 928.3 & 258.9 & 125.1 & 18.3 & 47.0 & 2.2 & 7.9 \\
\hline \multirow[t]{3}{*}{ Lakeshore } & $\mathrm{O}_{\mathrm{i}}$ & $+33 \sim+22$ & 3.5 & 36.3 & 5.7 & 363.1 & 12.7 & 934.1 & 103.0 & 561.8 & 0.7 & 1.9 & 0.5 & 0.9 \\
\hline & $\mathrm{O}_{\mathrm{e}}$ & $+22 \sim+9$ & 3.4 & 18.7 & 8 & 186.7 & 8.7 & 563.4 & 107.9 & 431.7 & 1.1 & 3.7 & 0.6 & 0.8 \\
\hline & $\mathrm{O}_{\mathrm{a}}$ & $+9 \sim 0$ & 3.5 & 17.7 & 7.3 & 176.9 & 7.4 & 945.8 & 124.6 & 417.3 & 0.4 & 1.4 & 0.3 & 1.3 \\
\hline
\end{tabular}

CEC: cation-exchange capacity; TOC: total organic $\mathrm{C} ; \mathrm{Fe}_{\mathrm{o}}, \mathrm{Al}_{\mathrm{o}}$ : iron and aluminum extracted by the ammonium oxalate method; $\mathrm{Fe}_{\mathrm{d}}, \mathrm{Al}_{\mathrm{d}}$ : iron and aluminum extracted by the citrate-bicarbonate-dithionite method.

Table 2. The fractionation of $\mathrm{P}\left(\mathrm{mg} \mathrm{kg}^{-1}\right)$ in humic soil samples (O horizon) in different topographic sites (sequential extraction).

\begin{tabular}{|c|c|c|c|c|c|c|c|c|c|c|c|c|c|}
\hline \multirow{2}{*}{ Site } & \multicolumn{5}{|c|}{ Inorganic $\mathbf{P}$ in Extracts } & \multirow{2}{*}{$\begin{array}{c}\text { Summed Inorganic } \mathbf{P} \\
\left(\mathbf{P}_{\mathrm{i}}\right)\end{array}$} & \multicolumn{3}{|c|}{ Organic $P$ in Extracts } & \multirow{2}{*}{$\begin{array}{c}\text { Summed Organic } \mathbf{P} \\
\left(\mathbf{P}_{\mathbf{o}}\right)\end{array}$} & \multirow{2}{*}{ Residual-P } & \multirow{2}{*}{ Summed $\mathbf{P}$} & \multirow{2}{*}{ Total P } \\
\hline & Resin- $P_{i}$ & $\mathrm{NaHCO}_{3}-\mathrm{P}_{\mathbf{i}}$ & $\mathrm{NaOH}-\mathrm{P}_{\mathrm{i}}$ & $\mathrm{HCl}_{-\mathbf{P}_{\mathrm{i}}}$ & cHCl-P $\mathbf{P}_{\mathbf{i}}$ & & $\mathrm{NaHCO}_{3}-\mathrm{P}_{\mathrm{o}}$ & $\mathrm{NaOH}-\mathrm{P}_{\mathrm{o}}$ & cHCl-P & & & & \\
\hline Summit & $4.8^{\mathrm{ab}}$ & $61.2^{\mathrm{a}}$ & $46.4^{\mathrm{b}}$ & 2.3 & 9.4 & $124.1^{\mathrm{ab}}$ & $124.4^{\mathrm{b}}$ & $415.6^{\mathrm{a}}$ & $20.6^{\mathrm{b}}$ & $560.6^{\mathrm{ab}}$ & 38.0 & $722.7^{\mathrm{ab}}$ & $757.0^{\mathrm{ab}}$ \\
\hline Footslope & $2.4^{\mathrm{b}}$ & $35.3^{\mathrm{b}}$ & $83.3^{\mathrm{a}}$ & 4.4 & 4.7 & $130.1^{\mathrm{a}}$ & $272.7^{\mathrm{a}}$ & $335.3^{\mathrm{ab}}$ & $31.6^{\mathrm{a}}$ & $639.6^{\mathrm{a}}$ & 29.4 & $799.0^{\mathrm{a}}$ & $828.3^{\mathrm{a}}$ \\
\hline Lakeshore & $7.3^{\mathrm{a}}$ & $25.4^{\mathrm{b}}$ & $36.4^{\mathrm{b}}$ & 5.9 & 9.9 & $84.8^{\mathrm{b}}$ & $177.5^{\mathrm{b}}$ & $306.5^{b}$ & $27.6^{\mathrm{ab}}$ & $511.5^{\mathrm{b}}$ & 34.9 & $631.2^{b}$ & $668.2^{b}$ \\
\hline
\end{tabular}

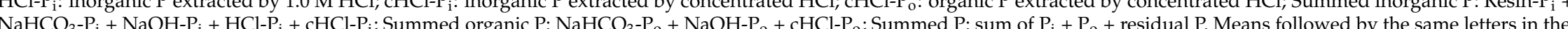

same column are not significantly different $(p>0.05)$ by Tukey's honestly significant difference test. 
Table 3. Relative proportions of total $\mathrm{P}$ extracted for inorganic $\left(\mathrm{P}_{\mathrm{i}}\right)$ and organic $\left(\mathrm{P}_{\mathrm{o}}\right)$ forms in $\mathrm{NaOH}$-EDTA extracts from humic soil samples (O horizon) determined by chemical extraction and

${ }^{31} \mathrm{P}-\mathrm{NMR}$ spectroscopy.

\begin{tabular}{|c|c|c|c|c|}
\hline \multirow{2}{*}{ Soil } & \multicolumn{2}{|c|}{$\mathbf{P}_{\mathbf{i}}$} & \multicolumn{2}{|c|}{$\mathbf{P}_{\mathbf{o}}$} \\
\hline & Chemical $\S$ & NMR & Chemical ${ }^{\S}$ & NMR \\
\hline & \multicolumn{4}{|c|}{$\%$} \\
\hline Summit & $17.2 \pm 2.8$ & $17.5 \pm 1.2$ & $77.5 \pm 2.9$ & $82.5 \pm 3.7$ \\
\hline Footslope & $16.3 \pm 2.1$ & $17.3 \pm 1.4$ & $80.0 \pm 2.4$ & $82.7 \pm 2.7$ \\
\hline Lakeshore & $16.9 \pm 1.4$ & $11.6 \pm 1.7$ & $81.1 \pm 1.5$ & $88.4 \pm 5.7$ \\
\hline
\end{tabular}

$\S P_{i}$ : sum of resin- $P_{i}+\mathrm{NaHCO}_{3}-\mathrm{P}_{\mathrm{i}}+\mathrm{NaOH}-\mathrm{P}_{\mathrm{i}}+\mathrm{HCl}-\mathrm{P}_{\mathrm{i}}+\mathrm{cHCl}-\mathrm{P}_{\mathrm{i}} \cdot \mathrm{P}_{\mathrm{o}}$ : sum of $\mathrm{NaHCO}_{3}-\mathrm{P}_{\mathrm{o}}+\mathrm{NaOH}-\mathrm{P}_{\mathrm{o}}+\mathrm{cHCl}-\mathrm{P}_{\mathrm{o}}$.

Spectra obtained from ${ }^{31} \mathrm{P}-\mathrm{NMR}$ analysis of $\mathrm{NaOH}-\mathrm{EDTA}$ extracts revealed inorganic orthophosphate, orthophosphate monoesters, orthophosphate diesters, pyrophosphates, and phosphonates in the soil extracts (Figure 3).

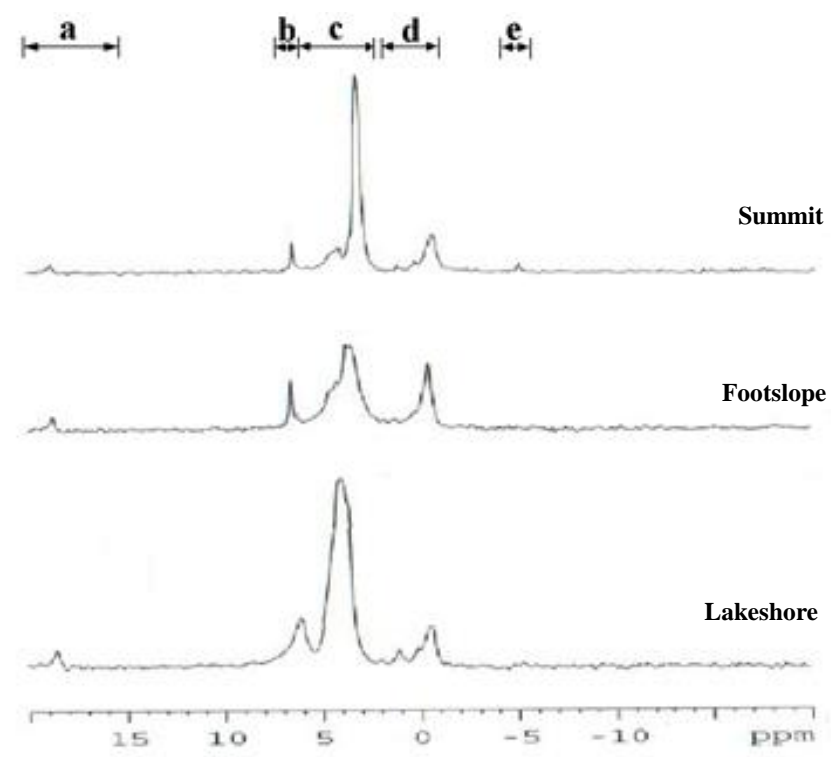

Figure 3. ${ }^{31} \mathrm{P}-\mathrm{NMR}$ spectra for $\mathrm{NaOH}-\mathrm{EDTA}$ extracts from soils at different sites. a: phosphonate, b: inorganic orthophosphate, c: orthophosphate monoesters, d: orthophosphate diesters, e: pyrophosphate.

Organic P compounds identified in the $\mathrm{NaOH}-\mathrm{EDTA}$ extracts included orthophosphate monoesters, orthophosphate diesters, and phosphonates. Orthophosphate monoesters were the predominant species of extracted organic $\mathrm{P}$ in soil from all sites and contributed to more than $60 \%$ of the total P fractions (Figure 4). The proportion of orthophosphate diesters was much lower than that of orthophosphate monoesters and only contributed $15 \%$ to $20 \%$ of the total P pools. Content of phosphonates (18.7 ppm) ranged from only $2.2 \%$ to $4.0 \%$ of extracted $P$ from the three sites, and the highest content was found at lakeshore, with waterlogged conditions.

Inorganic $\mathrm{P}$ compounds identified in the $\mathrm{NaOH}$-EDTA extracts included orthophosphate and pyrophosphates. Inorganic orthophosphate signals at $6.1-6.3 \mathrm{ppm}$ ranged from $11.6 \%$ to $17.3 \%$ of the spectral area for all study sites (Table 3). The highest inorganic P content was found at the footslope. In addition, small additional pyrophosphate resonance ( $-4.3 \mathrm{ppm})$ was observed only at the summit site. 


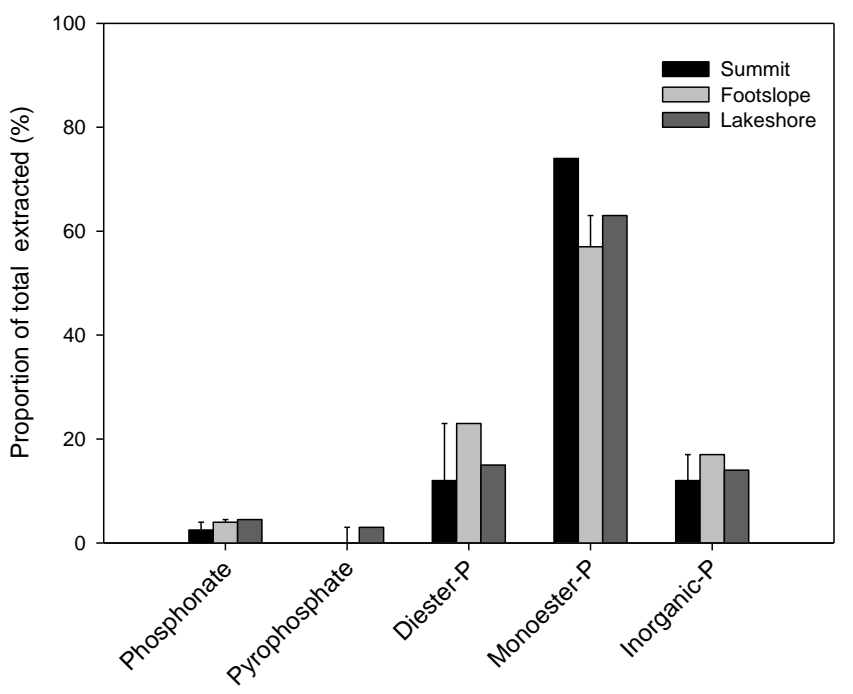

Figure 4. Proportion of extracted $P$ in various classes from humic samples at different sites determined by ${ }^{31} \mathrm{P}-\mathrm{NMR}$ spectroscopy. Error bars indicate standard deviation.

\section{Discussion}

\subsection{Soil Physiochemical Properties and Chemical Extractable P}

The soil in this study site contains high moisture because of the year-round high precipitation [45]. High soil moisture in mountainous forests retards decomposition of soil organic matter, and high precipitation increases the loss of cations, thereby resulting in decreased soil $\mathrm{pH}$ and Eh [38,46,47]. This explains our observations of low soil pH in the studied sites. Moreover, our previous study at the same sites revealed a clay and silt-clay layer under the organic layer [45]. This clay layer may retard the percolation [48] and therefore result in reduced soil TOC, TN and TP contents with increasing soil depth.

The high $\mathrm{Fe}_{\mathrm{o}}, \mathrm{Fe}_{\mathrm{d}}, \mathrm{Al}_{\mathrm{o}}$ and $\mathrm{Al}_{\mathrm{d}}$ contents in the $\mathrm{B}$ horizons implied that iron moved downwards and accumulated in the subsoil. Because high soil moisture and rich organic matter decreased soil redox potential in the surface layer, reduced $\mathrm{Fe}$ and $\mathrm{Al}$ ions moving from surface to the bottom layer were re-oxidized in the B horizons $[49,50]$. This formation of accumulated $\mathrm{Fe}$, which may due to the redoximorphic process [51,52], created a placic-like horizon and resulted in slow permeability of $P$ in such perhumid forest soil [49].

The positive correlations between $\mathrm{P}_{\mathrm{i}}$ and $\mathrm{Fe}_{\mathrm{d}}$ but not $\mathrm{P}_{\mathrm{i}}$ and $\mathrm{Fe}_{\mathrm{o}}$ contents implied that most inorganic $\mathrm{P}$ may be adsorbed by crystalline Fe oxides in soils, whereas the negative correlation between $\mathrm{P}_{\mathrm{o}}$ and $\mathrm{Fe}_{\mathrm{d}}$ as well as $\mathrm{P}_{\mathrm{o}}$ and $\mathrm{Fe}_{\mathrm{o}}$ contents implied that organic $\mathrm{P}$ was in a complex formation in the soils. In addition, the vertical increase in $P_{i}$ content, with an opposite trend to $P_{o}$ content, in each soil profile was significantly related to the content of amorphous and crystalline Fe oxides but not crystalline $\mathrm{Al}$ oxides. This observation implied that $\mathrm{Fe}$ oxides, rather than $\mathrm{Al}$ oxides, may chemically bind with $P_{i}$, and the accumulation of $P_{i}$ in the subsoils could relate to the downward percolation and reoxidation of Fe. Sollins et al. [53] found that soil with high Fe hydrous oxides content tends to irreversibly fix polyvalent oxyanions such as phosphate because of chemosorption and occlusion. A similar trend was found in our previous study of subalpine forest soils [54], in which significant sorption of $\mathrm{P}_{\mathrm{i}}$ to sesquioxides was via downward migration.

In addition, acidic soil conditions $(\mathrm{pH}<4)$ typically facilitate $\mathrm{Fe}$ oxides reduction (i.e., $\mathrm{Fe}^{2+}$ ), which may help the mobility of Fe in soil [55]. The acidic soils at this study site may further affect the mobility of $\mathrm{P}_{\mathrm{i}}$, thereby resulting in low $\mathrm{P}_{\mathrm{i}}$ content at the three study sites.

The depth of $\mathrm{O}$ horizons increased from the summit to the lakeshore, which suggests a process of erosion-deposition. In addition, because the mineral clay layer and placic-like horizon reduced 
vertical percolation, most of the soil organic matter in the water flow is transported laterally [33,45]. This can help the downhill movement of soil nutrients in the $O$ horizon $[45,49]$ and may explain the increased soil TOC and TN contents from the summit to the footslope. In addition, because the soils at the summit and footslope were relatively well-drained while the soils at the lakeshore were poorly-drained [33], this may help the accumulation of organic matter and result in a thick $\mathrm{O}$ horizon at the lakeshore.

\subsection{Chemical Extraction of Soil P}

Because of the low overall $P_{i}$ concentrations in the three study sites, the different chemical extractable $P_{i}$ contents increased downhill but not significantly. In addition, the low labile $P$ fractions, $\mathrm{NaHCO}_{3}-\mathrm{P}_{\mathrm{i}}$ and $\mathrm{NaOH}-\mathrm{P}_{\mathrm{i}}$, at the lakeshore may also be due to the vigorous fluctuation of the water level of the lake after showers or storms, which could remove the suspended particles or detritus of litter with the flooding and reduce the accumulation of $P$ in the soil near the lakeshore [30]. This was indirectly supported by the elevated TP concentration in the epilimnion of lake after medium rainfall events (256-620 mm) [56].

$\mathrm{P}_{\mathrm{o}}$ appeared to be the predominant fraction in the perhumid forest and was mostly non-acid extractable. Because the soil is acidic at the study sites, most $P_{o}$ fractions may not be labile and remained at higher values at the summit than at the lakeshore. The increase in total $P_{o}$ content in the surface horizon has been attributed to the input and accumulation of organic matter [57] and factors affected by topography can influence the availability of soil P [58].

Extracted soil $\mathrm{P}$ compounds showed that the contents of highly labile $\left(\mathrm{NaHCO}_{3}-\mathrm{P}_{\mathrm{o}}\right)$, long-term $\mathrm{P}$ transformation $\left(\mathrm{NaOH}-\mathrm{P}_{\mathrm{o}}\right)$ and stable residual pool $\left(\mathrm{cHCl}-\mathrm{P}_{\mathrm{o}}\right)$ fractions changed between different sites, which showed that slope position affects the various $P$ pools [59]. As shown in Table 2, the sum of the highly labile $\mathrm{P}_{\mathrm{o}}$ fraction $\left(\mathrm{NaHCO}_{3}-\mathrm{P}_{\mathrm{o}}\right)$ and long-term $\mathrm{P}$ transformation $\left(\mathrm{NaOH}-\mathrm{P}_{\mathrm{o}}\right)$ contributed more than $75 \%$ of the total extractable $\mathrm{P}$ in soils of all study sites, so organic $\mathrm{P}$ was the major $\mathrm{P}$ source in these soils. The $\mathrm{P}_{\mathrm{o}}$ accumulation in soil surfaces resulted from the biological cycling of $\mathrm{P}$ through the plant litter to the soil surface. In addition, we were aware that the density and height of understory Rhododendron were higher at the lakeshore than the footslope and summit, although we did not measure the abundance/density of the plants among the three sites. It could also be a potential factor causing the differences in $\mathrm{P}_{\mathrm{o}}$ accumulation.

The $\mathrm{cHCl}-\mathrm{P}_{\mathrm{i}}$ extract has recalcitrant $\mathrm{P}$ forms associated with mainly Fe oxides and/or P derived from non-alkaline extractable debris, whereas $\mathrm{cHCl}-\mathrm{P}_{\mathrm{o}}$ may include both stable, little and/or bioavailable (non-alkaline extractable) $\mathrm{P}$ forms. However, the proportions of $\mathrm{cHCl}$-extractable $\mathrm{P}_{\mathrm{i}}$ and $\mathrm{P}_{\mathrm{o}}$ were only about $4.5 \%$ to $7.5 \%$ of sequentially extracted total $\mathrm{P}$ in soils of all study sites. The residual $P$ is associated with highly organic materials such as lignin and organometallic complexes [60], but we have no information on the composition of organic matter in this fraction.

\subsection{Spectra of ${ }^{31} P$-NMR Analyses}

Orthophosphate monoesters are the most common forms of organic $P_{0}$ in soils [61-63]. Monoester P includes high proportions of inositol phosphate, sugar phosphate and choline phosphate primarily derived from plant, animal, and microbial residues [64].

Depending on the soil types, inositol phosphates are reported to be the predominant organic $\mathrm{P}$ forms in Podosols [28], whereas $\alpha$ - and $\beta$-glycerophosphate are the predominant organic $P$ forms in Vertosols [65]. In addition, high inositol phosphate contents were reported from several studies with cold and wet climates [66-68].

Inositol phosphates are typically considered of limited bioavailability because of the complex structure with soil minerals, clays, and humic compounds [62,69]. Although ${ }^{31} \mathrm{P}-\mathrm{NMR}$ analysis in our study had limited resolution to identify the inositol phosphates content, the low temperature and high precipitation of the study site may likely result in high inositol phosphates content in the soil. 
Orthophosphate diesters at about 0 ppm [42] can be further classified into nucleic acids (-1-0 ppm) and phospholipids (0-2 ppm) [62]. Orthophosphate diesters, including nucleic and phospholipids, more frequently accumulate in cool and moist acidic forest soils with low microbial activities than in agricultural soils [70-72]. In acidic or wet soils, diester P proportion is between $10 \%$ and $36 \%$ of extracted P [72-74]. Our findings are consistent with previous studies because the diester P proportion was between $15 \%$ and $20 \%$ of extracted $\mathrm{P}$ in the study sites.

A higher proportion of diester $\mathrm{P}$ providing a labile source for available $\mathrm{P}$ [75] was found at the footslope site, with poor drainage, than at the other sites. The lower orthophosphate diesters than monoesters content at the three study sites may contribute to the complexity of the chemical compounds. Orthophosphate diesters are more rapidly mineralizable than monoesters because they are generally less adsorbed to soil colloids than monoesters and can be easily hydrolyzed $[24,61,76]$.

The content of phosphonates in soil are due to bacteria such as Bacillus cereus, which has a phosphonatase enzyme that produces phosphonates, but the bacteria are less prevalent in acidic soil $[44,74,77]$. This observation may explain the low phosphonates concentrations observed at the study sites.

A small amount of pyrophosphate resonance ( $-4.3 \mathrm{ppm})$ was observed in spectra of soils at the three sites. Pyrophosphate is believed to be involved in biological $\mathrm{P}$ cycling in the soils and may be present in relatively well-drained soil that provides a proper environment for microbial activity and fungus [78]. In addition, pyrophosphate is contributed by fungal $\mathrm{P}$ compounds [79]. Because the surface soil of the three sites contained high soil organic matter and high soil moisture, it may provide a less favorable environment for microbial and fungal activities, resulting in low pyrophosphate concentrations.

Organic P represented between $82-88 \%$ and $77-81 \%$ of total $\mathrm{P}$ extracted by NaOH-EDTA and by chemical extraction from all sites studied, respectively. This result is similar to research byCade-Menun and Preston [80], who found $77 \%$ to $83 \%$ of $\mathrm{P}_{\mathrm{o}}$ in a low-pH forest perhaps because of the low decomposition of $\mathrm{P}_{\mathrm{o}}$ compounds in acidic forest soils that reduced the $\mathrm{P}_{\mathrm{i}}$ concentrations [44].

The signal intensity of ${ }^{31} \mathrm{P}-\mathrm{NMR}$ spectra caused by paramagnetic $\mathrm{Al}, \mathrm{Fe}$ and $\mathrm{Mn}$ in soils may reduce the spectra quality $[47,81,82]$. Moreover, chemical hydrolysis of $P_{o}$ to $P_{i}$ may occur during alkaline extractions $[80,83]$. However, in general, the results from NMR analysis were consistent with those of chemical fractionation in this study and other alpine and subalpine forest soils $[28,49,54,68]$.

\section{Conclusions}

This study demonstrated that soil chemical extractable $P_{i}$ and $P_{o}$ can be vertically affected by the formation of Fe oxides in soils. Because of a clay layer combined with a placic-like horizon in the subsoil in our test site, both total $\mathrm{P}$ and $\mathrm{P}_{\mathrm{o}}$ contents were decreased with increasing soil depth, with $\mathrm{P}_{\mathrm{i}}$ content slightly increased in different soil horizons. The low permeable soil layer also favored downhill run-off, however, because $P_{i}$ contents were relatively low compared with $P_{o}$ contents; the contents did not significantly differ among the three study sites. Because most of the $\mathrm{P}$ was in organic forms, a negligible amount of $P_{i}$ may be released to the lake along the slope. Therefore, although topography and soil formation processes affect the distribution of soil $\mathrm{P}$, high precipitation and year-round high humidity might be important for differentiation of the $\mathrm{P}$ species in this landscape. Moreover, the similarity of the ${ }^{31} \mathrm{P}$-NMR spectra among the three sampling sites supports the alleviated differentiation of the $\mathrm{P}$ species in this landscape. Preserving plant abundance and plant litters should be able to maintain soil $\mathrm{P}$ cycles and prevent the $\mathrm{P}$ discharge from subtropical alpine forest ecosystems.

Author Contributions: C.-Y.C. conceived the methodology and experimental design; J.-W.T., W.-C.L., R.S.W.Y., S.-C.C. and C.-Y.C. performed the experiments and analyzed the data; Y.-J.S. and C.-W.P. wrote the original draft; C.-Y.C. reviewed and edited the manuscript.

Acknowledgments: The study was granted by Academia Sinica and Ministry of Sciences and Technology (MOST 106-2621-M-239-001), Taiwan.

Conflicts of Interest: The authors declare no conflict of interest. 


\section{References}

1. Gutsch, M.; Lasch-Born, P.; Kollas, C.; Suckow, F.; Reyer, C.P.O. Balancing trade-offs between ecosystem services in Germany's forests under climate change. Environ. Res. Lett. 2018, 13, 045012. [CrossRef]

2. Pizzeghello, D.; Francioso, O.; Concheri, G.; Muscolo, A.; Nardi, S. Land use affects the soil C sequestration in alpine environment, NE Italy. Forests 2017, 8, 197. [CrossRef]

3. Wu, Y.H.; Zhou, J.; Yu, D.; Sun, S.Q.; Luo, J.; Bing, H.J.; Sun, H.Y. Phosphorus biogeochemical cycle research in mountainous ecosystems. J. Mt. Sci. 2013, 10, 43-53. [CrossRef]

4. Cassagne, N.; Remaury, M.; Gauquelin, T.; Fabre, A. Forms and profile distribution of soil phosphorus in alpine Inceptisols and Spodosols (Pyrenees, France). Geoderma 2000, 95, 161-172. [CrossRef]

5. Galloway, J.N.; Dentener, F.J.; Capone, D.G.; Boyer, E.W.; Howarth, R.W.; Seitzinger, S.P.; Asner, G.P.; Cleveland, C.C.; Green, P.A.; Holland, E.A.; et al. Nitrogen cycles: Past, present, and future. Biogeochemistry 2004, 70, 153-226. [CrossRef]

6. Amundson, R.; Jenny, H. On a state factor model of ecosystems. BioScience 1997, 47, 536-543. [CrossRef]

7. Vitousek, P.M.; Porder, S.; Houlton, B.Z.; Chadwick, O.A. Terrestrial phosphorus limitation: Mechanisms, implications, and nitrogen-phosphorus interactions. Ecol. Appl. 2010, 20, 5-15. [CrossRef] [PubMed]

8. Walker, T.W.; Syers, J.K. The fate of phosphorus during pedogenesis. Geoderma 1976, 15, 1-19. [CrossRef]

9. Chapin, F.I.; Mooney, H.; Chapin, M.; Matson, P. Principles of Terrestrial Ecosystem Ecology; Springer: New York, NY, USA, 2002.

10. Egli, M.; Filip, D.; Mavris, C.; Fischer, B.; Götze, J.; Raimondi, S.; Seibert, J. Rapid transformation of inorganic to organic and plant-available phosphorous in soils of a glacier forefield. Geoderma 2012, 189-190, 215-226. [CrossRef]

11. Achat, D.L.; Bakker, M.R.; Zeller, B.; Pellerin, S.; Bienaimé, S.; Morel, C. Long-term organic phosphorus mineralization in Spodosols under forests and its relation to carbon and nitrogen mineralization. Soil Biol. Biochem. 2010, 42, 1479-1490. [CrossRef]

12. Araújo, M.S.B.; Schaefer, C.E.R.; Sampaio, E.V.S.B. Soil phosphorus fractions from toposequences of semi-arid Latosols and Luvisols in northeastern Brazil. Geoderma 2004, 119, 309-321. [CrossRef]

13. Ciampitti, I.A.; García, F.O.; Picone, L.I.; Rubio, G. Phosphorus budget and soil extractable dynamics in field crop rotations in Mollisols. Soil Sci. Soc. Am. J. 2011, 75, 131. [CrossRef]

14. Zamuner, E.C.; Picone, L.I.; Echeverria, H.E. Organic and inorganic phosphorus in Mollisol soil under different tillage practices. Soil Tillage Res. 2008, 99, 131-138. [CrossRef]

15. Zhu, H.-J.; Sun, L.-F.; Zhang, Y.-F.; Zhang, X.-L.; Qiao, J.-J. Conversion of spent mushroom substrate to biofertilizer using a stress-tolerant phosphate-solubilizing Pichia farinose fl7. Bioresour. Technol. 2012, 111, 410-416. [CrossRef] [PubMed]

16. Cardoso, I.M.; Van der Meer, P.; Oenema, O.; Janssen, B.H.; Kuyper, T.W. Analysis of phosphorus by 31pnmr in Oxisols under agroforestry and conventional coffee systems in Brazil. Geoderma 2003, 112, 51-70. [CrossRef]

17. Vu, D.T.; Tang, C.; Armstrong, R.D. Transformations and availability of phosphorus in three contrasting soil types from native and farming systems: A study using fractionation and isotopic labeling techniques. J. Soils Sediments 2009, 10, 18-29. [CrossRef]

18. Achat, D.L.; Augusto, L.; Bakker, M.R.; Gallet-Budynek, A.; Morel, C. Microbial processes controlling P availability in forest Spodosols as affected by soil depth and soil properties. Soil Biol. Biochem. 2012, 44, 39-48. [CrossRef]

19. Zhang, Q.; Wang, Y.P.; Pitman, A.J.; Dai, Y.J. Limitations of nitrogen and phosphorous on the terrestrial carbon uptake in the 20th century. Geophys. Res. Lett. 2011, 38, L22701. [CrossRef]

20. Oberson, A.; Fardeau, J.C.; Besson, J.M.; Sticher, H. Soil phosphorus dynamics in cropping systems managed according to conventional and biological agricultural methods. Biol. Fertil. Soils 1993, 16, 111-117. [CrossRef]

21. Potter, R.L.; Jordan, C.F.; Guedes, R.M.; Batmanian, G.J.; Han, X.G. Assessment of a phosphorus fractionation method for soils: Problems for further investigation. Agric. Ecosyst. Environ. 1991, 34, 453-463. [CrossRef]

22. Ruttenberg, K.C. Development of a sequential extraction method for different forms of phosphorus in marine sediments. Limnol. Oceanogr. 1992, 37, 1460-1482. [CrossRef]

23. Tiessen, H.; Moir, J.O. Characterisation of available P by sequential extraction. In Soil Sampling and Methods of Analysis; Lewis Publisher: Boca Raton, FL, USA, 1993; pp. 75-86. 
24. Condron, L.M.; Frossard, E.; Tiessen, H.; Newmans, R.H.; Stewart, J.W.B. Chemical nature of organic phosphorus in cultivated and uncultivated soils under different environmental conditions. J. Soil Sci. 1990, 41, 41-50. [CrossRef]

25. Kizewski, F.; Liu, Y.-T.; Morris, A.; Hesterberg, D. Spectroscopic approaches for phosphorus speciation in soils and other environmental systems. J. Environ. Qual. 2011, 40, 751. [CrossRef] [PubMed]

26. Preston, C.M. Applications of nmr to soil organic matter analysis: History and prospects. Soil Sci. 1996, 161, 144-166. [CrossRef]

27. De Feudis, M.; Cardelli, V.; Massaccesi, L.; Bol, R.; Willbold, S.; Cocco, S.; Corti, G.; Agnelli, A. Effect of beech (Fagus sylvatica L.) rhizosphere on phosphorous availability in soils at different altitudes (central Italy). Geoderma 2016, 276, 53-63. [CrossRef]

28. Doolette, A.L.; Smernik, R.J.; McLaren, T.I. The composition of organic phosphorus in soils of the Snowy Mountains region of south-eastern Australia. Soil Res. 2017, 55, 10-18. [CrossRef]

29. Huang, W.; Liu, J.; Wang, Y.P.; Zhou, G.; Han, T.; Li, Y. Increasing phosphorus limitation along three successional forests in southern China. Plant Soil 2012, 364, 181-191. [CrossRef]

30. Xiao, R.; Bai, J.; Gao, H.; Huang, L.; Deng, W. Spatial distribution of phosphorus in marsh soils of a typical land/inland water ecotone along a hydrological gradient. Catena 2012, 98, 96-103. [CrossRef]

31. Ho, C.S. An Introduction to the Geology of Taiwan: Explanatory Text of the Geologic Map of Taiwan, 2nd ed.; Central Geological Survey: Taipei, Taiwan, 1988.

32. Soil Survey Staff. Keys to Soil Taxonomy, 12 ed.; Agricultural Handbook No 436; United States Department of Agriculture: Washington, DC, USA, 2014.

33. Chiu, C.-Y.; Lai, S.-Y.; Lin, Y.-M.; Chiang, H.-C. Distribution of the radionuclide ${ }^{137}$ Cs in the soils of a wet mountainous forest in Taiwan. Appl. Radiat. Isot. 1999, 50, 1097-1103. [CrossRef]

34. Rhoades, J.D. Soluble salts. In Methods of Soil Analysis Part 2, Chemical and Microbiological Properties; Page, A.L., Miller, R.H., Kenney, D.R., Eds.; Agronomy Monograph: Kincaid, DC, USA, 1982; Volume 9.

35. Mehra, O.P.; Jackson, M.L. Iron oxide removal from soils and clays by a dithionite-citrate system buffered with sodium bicarbonate. In Clays and Clay Minerals; Elsevier: New York, NY, USA, 2013; pp. 317-327.

36. McKeague, J.A.; Day, J.H. Dithionite- and oxalate-extractable Fe and Al as aids in differentiating various classes of soils. Can. J. Soil Sci. 1966, 46, 13-22. [CrossRef]

37. Hedley, M.J.; Stewart, J.W.B.; Chauhan, B.S. Changes in inorganic and organic soil phosphorus fractions induced by cultivation practices and by laboratory incubations. Soil Sci. S. Am. J. 1982, 46, 970. [CrossRef]

38. Richter, D.D.; Allen, H.L.; Li, J.; Markewitz, D.; Raikes, J. Bioavailability of slowly cycling soil phosphorus: Major restructuring of soil P fractions over four decades in an aggrading forest. Oecologia 2006, 150, 259-271. [CrossRef] [PubMed]

39. Rheinheimer, D.S.; Anghinoni, I.; Flores, A.F. Organic and inorganic phosphorus as characterized by phosphorus-31 nuclear magnetic resonance in subtropical soils under management systems. Commun. Soil Sci. Plant Anal. 2002, 33, 1853-1871. [CrossRef]

40. Lajtha, K.; Driscoll, C.; Jarrell, W.; Elliott, E. Soil phosphorous: Characterization and total element analysis. In Standard Soil Methods for Long-Term Ecological Research; Roberston, G., Coleman, D., Bledsoe, C., Sollins, P., Eds.; Oxford University Press: Oxford, UK, 1999.

41. Robinson, J.S.; Johnston, C.T.; Reddy, K.R. Combined chemical and ${ }^{31}$ P-NMR spectroscopic analysis of phosphorus in wetland organic soils. Soil Sci. 1998, 163, 705-713. [CrossRef]

42. Newman, R.H.; Tate, K.R. Soil phosphorus characterisation by ${ }^{31}$ P nuclear magnetic resonance. Commun. Soil Sci. Plant Anal. 1980, 11, 835-842. [CrossRef]

43. Preston, C.M. Review of solution NMR of humic substances. In NMR of Humic Substances and Coal; Wershaw, R.L., Mikita, M.A., Eds.; Lewis Publisher: Chelsea, MI, USA, 1987; pp. 3-32.

44. Dai, K.O.H.; David, M.B.; Vance, G.F.; Krzyszowska, A.J. Characterization of phosphorus in a spruce-fir Spodosol by phosphorus-31 nuclear magnetic resonance spectroscopy. Soil Sci. Soc. Am. J. 1996, 60, 1943. [CrossRef]

45. Chen, J.-S.; Chiu, C.-Y. Effect of topography on the composition of soil organic substances in a perhumid sub-tropical montane forest ecosystem in taiwan. Geoderma 2000, 96, 19-30. [CrossRef]

46. Ohno, T.; Fernandez, I.J.; Hiradate, S.; Sherman, J.F. Effects of soil acidification and forest type on water soluble soil organic matter properties. Geoderma 2007, 140, 176-187. [CrossRef] 
47. Prietzel, J.; Dümig, A.; Wu, Y.; Zhou, J.; Klysubun, W. Synchrotron-based P k-edge XANES spectroscopy reveals rapid changes of phosphorus speciation in the topsoil of two glacier foreland chronosequences. Geochim. Cosmochim. Acta 2013, 108, 154-171. [CrossRef]

48. Candler, R.; Zech, W.; Alt, H.G. A comparison of water soluble organic substances in acid soils under beech and spruce in NE-Bavaria. Z. Pflanz. Bodenk. 1989, 152, 61-65. [CrossRef]

49. Jien, S.H.; Baillie, I.; Hu, C.-C.; Chen, T.-H.; Iizuka, Y.; Chiu, C.-Y. Forms and distribution of phosphorus in a placic podzolic toposequence in a subtropical subalpine forest, Taiwan. Catena 2016, 140, 145-154. [CrossRef]

50. Jien, S.H.; Hseu, Z.Y.; Iizuka, Y.; Chen, T.H.; Chiu, C.Y. Geochemical characterization of placic horizons in subtropical montane forest soils, northeastern Taiwan. Eur. J. Soil Sci. 2010, 61, 319-332. [CrossRef]

51. Hseu, Z.-Y.; Chen, Z.-S.; Wu, Z.-D. Characterization of placic horizons in two subalpine forest Inceptisols. Soil Sci. Soc. Am. J. 1999, 63, 941. [CrossRef]

52. Wu, S.P.; Chen, Z.S. Characteristics and genesis of Inceptisols with placic horizons in the subalpine forest soils of Taiwan. Geoderma 2005, 125, 331-341. [CrossRef]

53. Sollins, P.; Robertson, G.P.; Uehara, G. Nutrient mobility in variable- and permanent-charge soils. Biogeochemistry 1988, 6, 181-199. [CrossRef]

54. Chiu, C.-Y.; Pai, C.-W.; Yang, K.-L. Characterization of phosphorus in sub-alpine forest and adjacent grassland soils by chemical extraction and phosphorus-31 nuclear magnetic resonance spectroscopy. Pedobiologia 2005, 49, 655-663. [CrossRef]

55. Spark, D.L. Environmental Soil Chemistry; Academic Press: Cambridge, MA, USA, 1995.

56. Tsai, J.-W.; Kratz, T.K.; Hanson, P.C.; Kimura, N.; Liu, W.-C.; Lin, F.-P.; Chou, H.-M.; Wu, J.-T.; Chiu, C.-Y. Metabolic changes and the resistance and resilience of a subtropical heterotrophic lake to typhoon disturbance. Can. J. Fish. Aquat. Sci. 2011, 68, 768-780. [CrossRef]

57. Smeck, N.E. Phosphorus. Soil Sci. 1973, 115, 199-206. [CrossRef]

58. Smeck, N.E. Phosphorus dynamics in soils and landscapes. Geoderma 1985, 36, 185-199. [CrossRef]

59. Agbenin, J.O.; Tiessen, H. Phosphorus forms in particle-size fractions of a toposequence from northeast Brazil. Soil Sci. Soc. Am. J. 1995, 59, 1687. [CrossRef]

60. Schlichting, A.; Leinweber, P.; Meissner, R.; Altermann, M. Sequentially extracted phosphorus fractions in peat-derived soils. J. Plant Nutr. Soil Sci. 2002, 165, 290-298. [CrossRef]

61. Fox, T.R.; Miller, B.W.; Rubilar, R.; Stape, J.L.; Albaugh, T.J. Phosphorus nutrition of forest plantations: The role of inorganic and organic phosphorus. In Soil Biology; Springer: Berlin/Heidelberg, Germany, 2010; pp. 317-338.

62. Turner, B.L.; Mahieu, N.; Condron, L.M. Quantification of myo-inositol hexakisphosphate in alkaline soil extracts by solution ${ }^{31} \mathrm{P}$ NMR spectroscopy and spectral deconvolution. Soil Sci. 2003, 168, 469-478. [CrossRef]

63. Turner, B.L.; Mahieu, N.; Condron, L.M.; Chen, C.R. Quantification and bioavailability of scyllo-inositol hexakisphosphate in pasture soils. Soil Biol. Biochem. 2005, 37, 2155-2158. [CrossRef]

64. Magid, J.; Tiessen, H.; Condron, L.M. Dynamics of organic phosphorus in soils under natural and agricultural ecosystems. In Humic Substances in Terrestrial Ecosystems; Elsevier: New York, NY, USA, 1996; pp. 429-466.

65. McLaren, T.I.; Smernik, R.J.; Guppy, C.N.; Bell, M.J.; Tighe, M.K. The organic P composition of Vertisols as determined by ${ }^{31}$ P NMR spectroscopy. Soil Sci. Soc. Am. J. 2014, 78, 1893. [CrossRef]

66. Ahlgren, J.; Djodjic, F.; Börjesson, G.; Mattsson, L. Identification and quantification of organic phosphorus forms in soils from fertility experiments. Soil Use Manag. 2013, 29, 24-35. [CrossRef]

67. Turner, B.L.; Cheesman, A.W.; Godage, H.Y.; Riley, A.M.; Potter, B.V.L. Determination of neo- and D-chiro-inositol hexakisphosphate in soils by solution ${ }^{31}$ P NMR spectroscopy. Environ. Sci. Technol. 2012, 46, 4994-5002. [CrossRef] [PubMed]

68. Vincent, A.G.; Vestergren, J.; Gröbner, G.; Persson, P.; Schleucher, J.; Giesler, R. Soil organic phosphorus transformations in a boreal forest chronosequence. Plant Soil 2013, 367, 149-162. [CrossRef]

69. Turner, B.L.; Newman, S.; Cheesman, A.W.; Reddy, K.R. Sample pretreatment and phosphorus speciation in wetland soils. Soil Sci. Soc. Am. J. 2007, 71, 1538. [CrossRef]

70. Cade-Menun, B.J. Characterizing phosphorus in environmental and agricultural samples by ${ }^{31} \mathrm{P}$ nuclear magnetic resonance spectroscopy. Talanta 2005, 66, 359-371. [CrossRef] [PubMed]

71. Cade-Menun, B.J.; Berch, S.M.; Preston, C.M.; Lavkulich, L.M. Phosphorus forms and related soil chemistry of podzolic soils on northern Vancouver Island. I. A comparison of two forest types. Can. J. For. Res. 2000, 30, 1714-1725. [CrossRef] 
72. Makarov, M.I.; Guggenberger, G.; Zech, W.; Alt, H.G. Organic phosphorus species in humic acids of mountain soils along a toposequence in the northern Caucasus. Z. Pflanz. Bodenk. 1996, 159, 467-470. [CrossRef]

73. Forster, J.C.; Zech, W. Phosphorus status of a soil catena under liberian evergreen rain forest: Results of ${ }^{31} \mathrm{P}$ NMR spectroscopy and phosphorus adsorption experiments. Z. Pflanz. Bodenk. 1993, 156, 61-66. [CrossRef]

74. Zech, W.; Alt, H.G.; Haumaier, L.; Blasek, R. Characterization of phosphorus fractions in mountain soils of the Bavarian Alps by ${ }^{31}$ P NMR spectroscopy. Z. Pflanz. Bodenk. 1987, 150, 119-123. [CrossRef]

75. Miltner, A.; Haumaier, L.; Zech, W. Transformations of phosphorus during incubation of beech leaf litter in the presence of oxides. Eur. J. Soil Sci. 1998, 49, 471-475. [CrossRef]

76. Condorn, L.; Frossard, E.; Newman, R.H. Use of ${ }^{31} \mathrm{P}$ NMR in the study of soils and the environment. In Nuclear Magnetic Resonance Spectroscopy in Environmental Chemistry; Oxford University Press: New York, NY, USA, 1997; pp. 247-271.

77. Tate, K.R.; Newman, R.H. Phosphorus fractions of a climosequence of soils in New Zealand tussock grassland. Soil Biol. Biochem. 1982, 14, 191-196. [CrossRef]

78. Rousk, J.; Brookes, P.C.; Baath, E. Contrasting soil ph effects on fungal and bacterial growth suggest functional redundancy in carbon mineralization. Appl. Environ. Microbiol. 2009, 75, 1589-1596. [CrossRef] [PubMed]

79. Makarov, M.I.; Haumaier, L.; Zech, W.; Marfenina, O.E.; Lysak, L.V. Can ${ }^{31}$ P NMR spectroscopy be used to indicate the origins of soil organic phosphates? Soil Biol. Biochem. 2005, 37, 15-25. [CrossRef]

80. Cade-Menun, B.J.; Preston, C.M. A comparison of soil extraction procedures for ${ }^{31} \mathrm{P}$ NMR spectroscopy. Soil Sci. 1996, 161, 770-785. [CrossRef]

81. Bol, R.; Amelung, W.; Haumaier, L. Phosphorus-31-nuclear magnetic-resonance spectroscopy to trace organic dung phosphorus in a temperate grassland soil. J. Plant Nutr. Soil Sci. 2006, 169, 69-75. [CrossRef]

82. Hedges, J.I.; Oades, J.M. Comparative organic geochemistries of soils and marine sediments. Org. Geochem. 1997, 27, 319-361. [CrossRef]

83. Leinweber, P.; Haumaier, L.; Zech, W. Sequential extractions and ${ }^{31}$ P-NMR spectroscopy of phosphorus forms in animal manures, whole soils and particle-size separates from a densely populated livestock area in northwest Germany. Biol. Fertil. Soils 1997, 25, 89-94. [CrossRef]

(C) 2018 by the authors. Licensee MDPI, Basel, Switzerland. This article is an open access article distributed under the terms and conditions of the Creative Commons Attribution (CC BY) license (http:/ / creativecommons.org/licenses/by/4.0/). 